\title{
'The company will fire you because you are too expensive': a photo-ethnography of health care rights among Filipino migrant seafarers
}

\author{
Shannon Guillot-Wright (iD ${ }^{1 凶}$
}

With fatal injuries six times the rate of all US occupations, people who live and work at sea are part of one of the most dangerous occupations. Few ships have health care workers aboard despite many seafarers being at sea for months. While seafarers are guaranteed a right to health care through maritime labor laws and conventions, it is unclear whether or how they access these rights. Therefore, photo-ethnography was used to examine what health care access means for seafarers through the lens of structural violence. The study site was the vessel the seafarers worked and lived on, which docked in the Gulf of Mexico once-aweek, flies a flag of convenience, and travels in international waters. The photo-ethnography was implemented over a one-year period and included male Filipino seafarers who worked 9-month contracts at sea. The historical, structural, and political-economic production of injury, illness, and death were questioned to understand why migrant seafarers do not have de facto access to their de jure health rights. In this way, health prevention was analyzed through the discourse of power distribution instead of risk and disease. Results from the project reveal that seafarers routinely underreport adverse work and health conditions for fear of losing future work contracts. Adverse work experiences included dangerous vessels and routes as well as being encouraged to work with little sleep or through storms. Adverse health issues included severe to moderate injury and illness, which they concealed from management. Ultimately, it was revealed that political-economic systems are internalized and embodied among migrant workers who are employed under short-term contracts, leading to decreased healthcare-seeking behaviors and increased health disparities.

\footnotetext{
${ }^{1}$ University of Texas Medical Branch, Galveston, USA. ${ }_{\text {email: spguillo@utmb.edu }}$
} 


\section{Background}

igrant seafarers, people who live and work at sea, are part of one of the most dangerous occupations. Seafaring, which is largely a hidden industry because of its location at sea, accounts for over $90 \%$ of global trade and employs over 1.5 million workers (George, 2013). Fatal injuries are nearly six times the rate of all US occupations and seafarers are disproportionately more likely to experience cardiovascular conditions, work accidents, drownings, vessel disasters, suicides, and workplace violence (CDC, 2020). Few ships have healthcare workers aboard or internet access for telehealth; alarming given that seafarers are often at sea for weeks or months at a time, away from family, social networks, and other resources (MacLachlan et al., 2012). Furthermore, the inaccessibility of seafarers makes them a difficult population to study.

Seafarers are often put in the category of 'circulant migrants' (e.g., farmers, fishers) due to the contractual and temporary nature of their jobs, frequent travel between their country of origin and work, and remittances they send home. However, seafarers are unique from many circulant migrant workers because they are required to obtain passports and visas, which guarantees them certain healthcare rights when sick or injured (Standing, 2014; Markkula, 2021). Given their status as documented migrants, seafarers appear to have greater access to healthcare rights within the US legal and political system. They are guaranteed protections through international laws like the 'International Maritime Labour Convention' 2006 (MLC) and through US laws like the 'Jones Act' and 'Maintenance and cure' (McDaniel, 1990; Maritime Labour Convention, 2006; ITF, 2006).

According to the MLC, flag states (i.e., the jurisdiction of the vessel and whose laws the vessel must follow) are responsible for the health protection of seafarers while they are onboard the vessel. States that have signed the MLC must provide free medical care to seafarers when they are in their territory, and shipowners are responsible for the costs of illness, injury, or death while the seafarers are in their employment (ITF, 2006). In theory, these protections seem adequate to cover the health issues or medical costs that seafarers experience onboard a vessel or in port. In practice, however, overlapping and jurisdictional mazes allow the shipping industry to safeguard companies through flags of convenience and contractual loopholes, which often prove to be pernicious to seafarers' health and well-being.

Although the US has not ratified the MLC, US shipping companies are still required to pay for certain benefits for seafarers based on maintenance and cure and the Merchant Marine Act of 1920 (also known as the Jones Act). Maintenance and cure is one of the oldest laws that express protections for seafarers from the severity of life at sea at the cost of the shipowners (McDaniel, 1990). The doctrine was based "on the belief that the vessel served as the seaman's home and the seaman should be entitled to continue receiving lodging and food even when sick" and US courts granted maintenance and cure "regardless of the seaman's employment contract” (McDaniel, 1990, p. 669).

The Jones Act further guarantees "a seafarer's right to a trial by jury as a remedy to recover damages in the case of injuries sustained while under contract to work aboard a ship" (Terry, 2009). In essence, workers on a US-owned ship can seek legal remedy in the US, even if the seafarer is a foreign citizen (Terry, 2009). The Jones Act, which provides additional protections to maintenance and cure is based on where a shipowner operates (e.g., United States) as opposed to the citizenship of the seafarer (e.g., Filipino) (Terry, 2009). In these instances, the legal domicile of the ship companies and not land, citizenship, international waters, or contractual agreements serve as the space of recognition for seafarers to have legal recourse for injuries, sickness, and other health-related diseases.
While maintenance and cure and the Jones Act are still legally in effect, recent court decisions (see Bautista $v$. Star Cruises and Francisco v. STOLT ACHIEVEMENT MT) have rendered them merely nominal (Terry, 2009). These cases set a precedent that allows for the removal of cases from US courts and automatically compels them to arbitration in the Philippines (Terry, 2009). Mandatory arbitration is a process where legal disputes, such as injuries at sea, are resolved privately instead of through court. The precedent of the Bautista and Francisco cases affects all seafarers who have arbitration agreements in their contracts. This arrangement disproportionately affects Filipino seafarers since they makeup nearly one-third of the seafaring industry and must sign contracts that include mandatory arbitration and nonprotected sick leave (Terry, 2009). Filipino seafarers are forbidden from claiming damages in US courts and must instead arbitrate their claims in the Philippines (Terry, 2009). The growing health disparities resulting from mandatory arbitration have been widely documented, including seafarers receiving little to no compensation for workplace injuries like back impairments or amputations (Terry, 2009; Smith, 2016; Presser, 2017).

Contractual policies that Filipino seafarers must agree to can be traced to the Philippine's labor export program, which is enforceable under Philippine law (Rodriguez, 2010; Marcos, 1982). The program is a state-based arrangement that recruits and contracts labor directly to foreign employers, such as seafaring companies. The state negotiates contracts with companies while profiting from the labor of those contracts through enforced remittances (Rodriguez, 2010; Marcos, 1982). Arrangements like the labor export program have made Filipino people one of the largest exported commodities in the world, as well as one of the most precarious (Rodriguez, 2010).

Laws and conventions like the MLC, the Jones Act, and maintenance and cure were important and necessary steps in the attainment of healthcare rights for migrant seafarers, but contractual deregulations like mandatory arbitration and non-protected sick leave have decentered the healthcare rights of Filipino seafarers (Rodriguez, 2010). Moreover, the MLC provides little support for seafarers to actualize worker representation or consultation to improve occupational safety and health (Graham and Walters, 2021). Little is known about how migrant Filipino seafarers actually seek medical care within precarious political-economic structures (e.g., labor export programs or contractual deregulations) and whether their future employment is protected. To summarize the above, the right for Filipino migrant seafarers to seek medical care aboard a ship and while in port are guaranteed by law; however, the lived experiences of seafarers may tell a different story for what seeking healthcare means for these precarious workers.

As I argue throughout this article, Filipino migrant seafarers experience a continuum of violence, and specifically structural violence, which is embodied in their lived experiences of seeking or circumventing healthcare (Scheper-Hughes, 2004; Bourgois, 2007). Structural violence, which comes out of Latin America's liberation theology, are the ways that our system is structured to produce differential outcomes among different populations, and then subsequently holds the poor accountable for their poverty instead of the social origins of their poverty (Scheper-Hughes, 2004; Farmer and Sen, 2004). To interrogate and understand how Filipino seafarers experience structural violence, I spent nearly a year with a crew of Filipino migrant seafarers in a US Gulf of Mexico port, exploring the ways they interact within and outside of healthcare systems.

\section{Methods}

This research was conducted as part of a larger photoethnography focused on human rights and healthcare access. Fieldwork was conducted between December 2016 and October 
2017 in a US-based Gulf of Mexico port with a crew of all-male, English-speaking Filipino migrant seafarers $(n=14)$. Data was collected through semi-structured interviews, observation, photovoice, and field notes aboard the ship when the vessel was in port, at the local seafarer's center where seafarers went for respite, and when transporting seafarers to local stores to buy clothes, electronics, toiletries, or other goods (Davies, 2009). Ethnographic research was undertaken with the goals of listening to and observing the lived experiences of participants over an extended period of time and visually seeing those experiences through their photographs (Rosaldo, 1989). Fourteen semi-structured interviews and six photovoice projects were conducted with seafarers, as well as semi-structured interviews with two key stakeholdersa Chaplain who visited the ship frequently and a former lawyer who worked closely with seafaring human rights agencies. The study was approved by the University of Texas Medical Branch's Institutional Review Board and performed in accordance with ethical guidelines and regulations. All names have been changed to protect the identity of participants.

The combination of traditional ethnographic methods (i.e., observation, informal conversation) with photovoice made this a co-produced photo-ethnography that centered seafarer's perspectives and experiences (Sutton-Brown, 2014; Bourgois and Schonberg, 2009). Photovoice is a method that offers participants the opportunity to take photographs that are representative of their lives and serves the purpose of exploring social issues from the people who personally experience them. Historically, photovoice has been an effective tool to communicate people's shared knowledge and expertize (Wang and Burris, 1997). Although photovoice has given participants a different vehicle to participate in the research process, the use of photography in research is not without its critiques and history of misuses and abuses (Bourgois and Schonberg, 2009). For this study, the tensions in visual ethnography were mitigated by asking participants to take photographs (instead of taking photos of them) and then we analyzed the photographs together as data, not as an all-encompassing representation of their lives (Bourgois and Schonberg, 2009; Wright, 2016).

Participants who agreed to photovoice were given the choice between a film camera or their phones and a one-page explanation about the purpose of the project. The participants who used the film camera $(n=3)$ were given instructions about how to use it as well as when to return it, and participants who used mobile phones $(n=3)$ were given instructions about how to send their photos. One of the rolls of the film could not be exposed, but all other images were printed and delivered to the seafarers. Seafarers were given 4-6 weeks to take photographs, and then described their photos and reasoning for a particular photo. The primary purpose of the photographs was to understand what the seafarers identified as important regarding their health and well-being (Wright, 2016).

The photovoice process showed how the seafarers I collaborated with could not be reduced to passive victims who were caught in systems of oppression. When asked to photograph their lives, they took pictures of storms and celebrations; pictures of men working with backs bent as well as pig roasts and pool parties. It was in these paradoxes and shared vulnerability of photographs (I also shared photographs of my life with them) that our lived experiences crossed, illuminating our collective complicity in the globalized food industry, as well as diverted, revealing my privilege as I drove away from the port every Monday.

Access and selection process. Access to the ship included bureaucratic approval and rapport building, such as obtaining (1) a Transportation Workers Identification Card (TWIC); (2) an Escort Pass (e.g., to take the seafarers to a local convenience store); (3) approval from the captain; and (4) daily approval from port authority guards. Due to US laws and regulations, I was not allowed to sail with the crew as an untrained seafarer. Therefore, I chose to study a reefer vessel that docked every week at the same port so I would have the opportunity to interact with the same crew during their entire 9-month contract. Photovoice was also a practical tool that allowed me to see their lives since I could not travel between ports. Interactions took place once-a-week when the seafarers were in port (the only weeks missed were when the ship went into dry dock and when it was rerouted due to storms). Interactions included (1) formal interviews, (2) informal activities when they were off-duty, such as playing basketball on the ship or taking them on trips to the mall, and (3) observing their work when they were on-duty, like crane malfunctions or interactions with the Coast Guard. I typically stayed in the mess hall drinking Nescafe, watching music videos, and having informal conversations with off-duty seafarers to stay out of the way of their work, unless invited to observe activities.

Consistent with best practices (Trimble et al., 2011), seafarers were asked to take part in the photovoice project after they participated in interviews to build trust and rapport as well as to ensure they had sufficient time to understand the project and not feel pressured to participate; especially important since questions were related to their work environment. All participants on the vessel consented to both the interview and photovoice project and were given additional resources about the use and disclosure of their photographs. The captain and chief cook provided access to a confidential meeting space. Seafarers were sampled for photovoice based on whether they completed an interview, their position on the ship, and whether we had built the necessary rapport, therefore limiting the number of photovoice participants. This process is consistent with the literature that shows no relationship between group size and quality of participation (Catalani and Minkler, 2010). To have a representative sample of the ship's hierarchy and work duties, the photovoice participants included the captain, second officer, second engineer (film too underexposed for use), mid-ranking seafarer (i.e., able-bodied seaman), and lower-ranking seafarers (i.e., chief cook and mess man).

Data analysis. Data analyses involved a two-stage inductive approach to identify key themes and discourses that emerged from narrative data, followed by a more intensive discourse analysis that explored the different rationalities and rhetoric employed by participants (Davies, 2009). First, a thematic coding of all interviews was undertaken. Specifically, open coding was done to identify themes regarding injury, illness, and healthcare access. Updates were made iteratively to include new relevant subthemes identified throughout data collection and analysis. Additionally, positionality, power, and representation were taken into account when analyzing data, with the full understanding that we were influenced and influencing simultaneously. Issues of positionality, power, and representation were mitigated by having open communication with the participants, such as seeking clarification, being open about findings, and sending manuscripts that were produced from the research. The ultimate goal was to show an ethical representation of the lives of migrant seafarers that was accountable for revealing multiple layers of life experiences.

\section{Results}

When I boarded the reefer vessel each Monday, there were sounds of pelicans squeaking, water crashing, honks, beeps, cranes, wind, and men yelling at each other. I typically began each interview asking the seafarers about their lives at sea or their daily routines, often finding myself enamored with the sounds and 


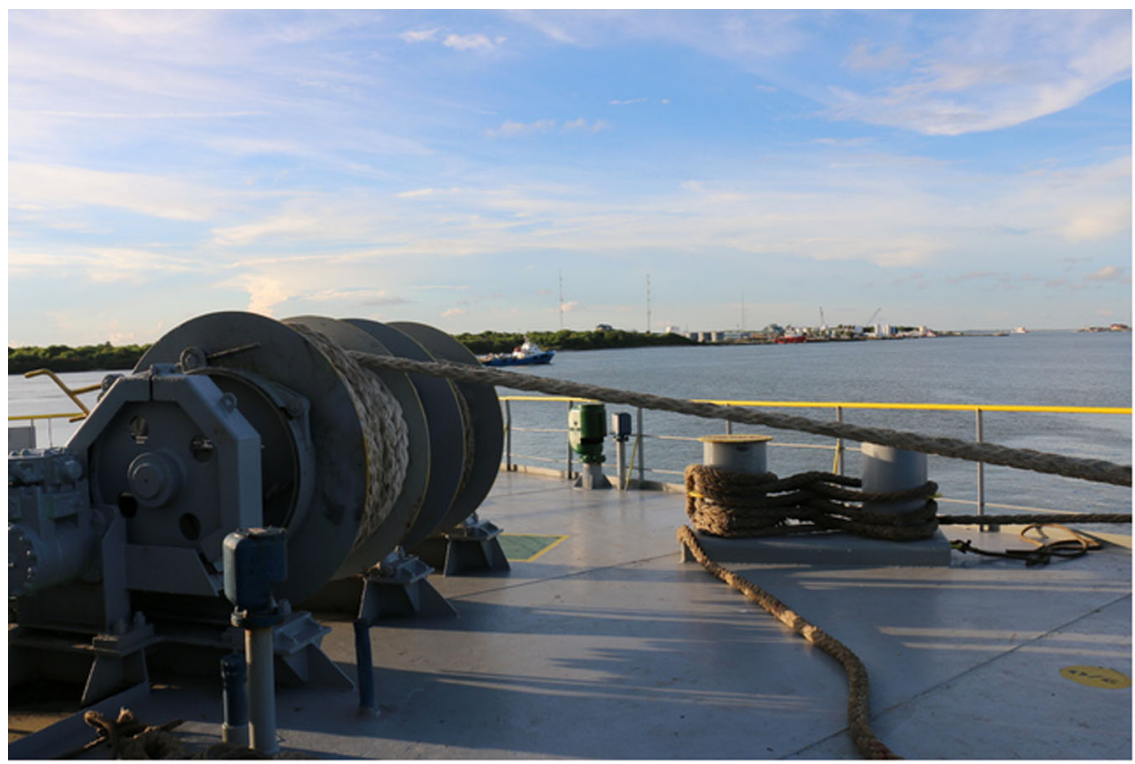

Fig. 1 Ropes on ship. Photograph taken by the author of the ropes described by a seafarer as dangerous.

sights of the harbor. However, their stories quickly reminded me that my perspective of the ocean as beautiful and romantic was a privileged perspective.

Diego, the Captain of the reefer vessel, told me about the time he was held hostage by pirates, and Jay, the Third Officer, told me about his experience drifting at sea for 21 days: "When you sleep, there is water. When you wake up, there is still water." The sea was far from tranquil for Jay and his colleagues when provisions began to decrease, and although they had money, they had nowhere to buy food. They had been sailing for 55 days and drifting for 21 days 150 miles from shore, waiting for port orders, with only rice and the fish they caught.

Seafarers are cognizant of the dangers on their vessels and at sea. Roberto, an Ordinary Seaman (OS) who works on the deck, specifically mentioned ropes as a constant source of danger on the ship (see Fig. 1). He said, "Yes, it is dangerous [being a seafarer]. The ropes...sometimes it can hit like [demonstrated the ropes hitting him], so we must always be aware. You could be on the other side [and get hit]. You must be very aware of where you are." Later in the interview, Roberto said that the lack of sleep, stress, and the environment were also part of the dangers of being a seafarer. He said, "Sometimes you get confused, scared."

Roberto, the father of a 6-year-old boy, a 4-year-old girl, a 2year-old girl told me he talked to his family or saw them in pictures on Facebook every time he was in port (in this case, once a week, but on other ships he has been on it could be weeks to months). He started off as a nursing student but was afraid he would have a difficult time finding work, so switched to the maritime academy since his father was a seafarer and could help him find work. He said missing his family is what causes him the most stress, especially when his wife tells him to "please come home." When we met, he was 7 months into his 9-month contract and told me he already had his bags packed, "I'm ready, my stuff is ready... two months, that's too far, but I'm already excited." He later told me,

For me, it is a sacrifice. You never see your son [or] your daughter grow up. [Speaking about his children being born and growing up] He came out, the first word, he walked-I didn't see. My father was a seafarer for 25 years and there was something that came between us that I cannot explain... but when I came to college, I realized his

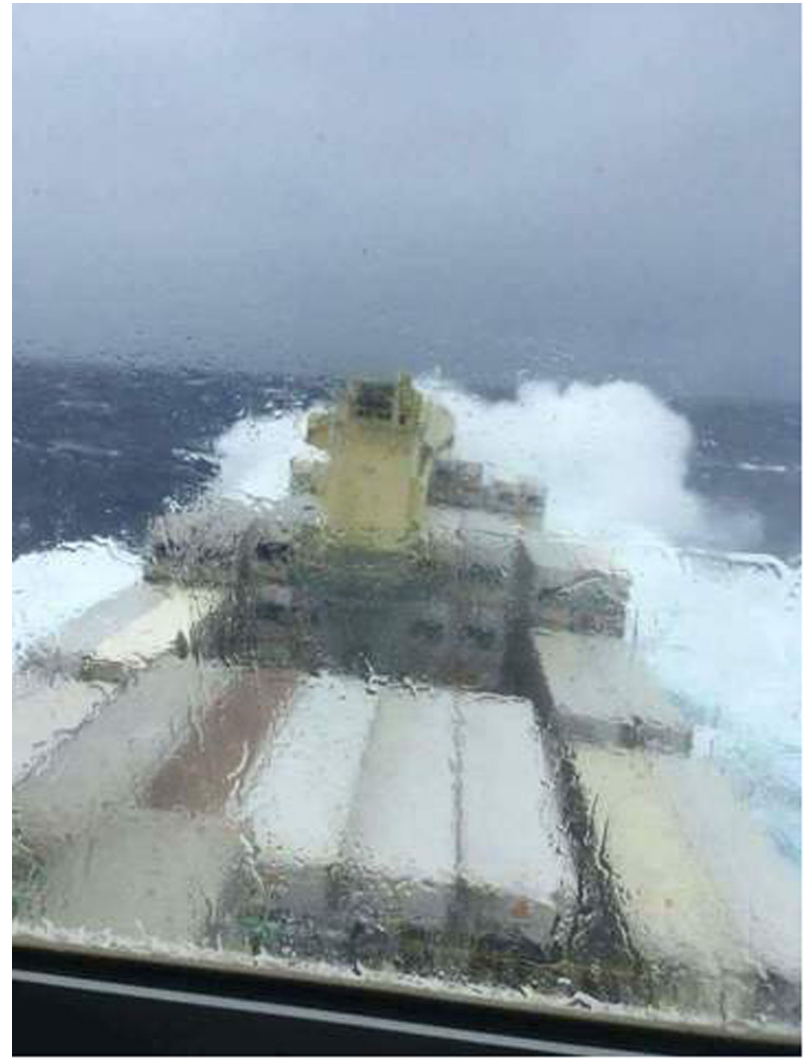

Fig. 2 Tropical Storm. Photograph taken by a participant of waves coming over the cargo.

sacrifices... And so that's my problem right now with my children. That they will grow up and not know me... So, when I come to port I Facebook and talk to them.

When I asked Roberto about his health and work and if he had been injured, he responded matter-of-factly, "Always."

In the single year that I spent with the seafarers they went through one major storm at sea (see Fig. 2), one tropical storm 


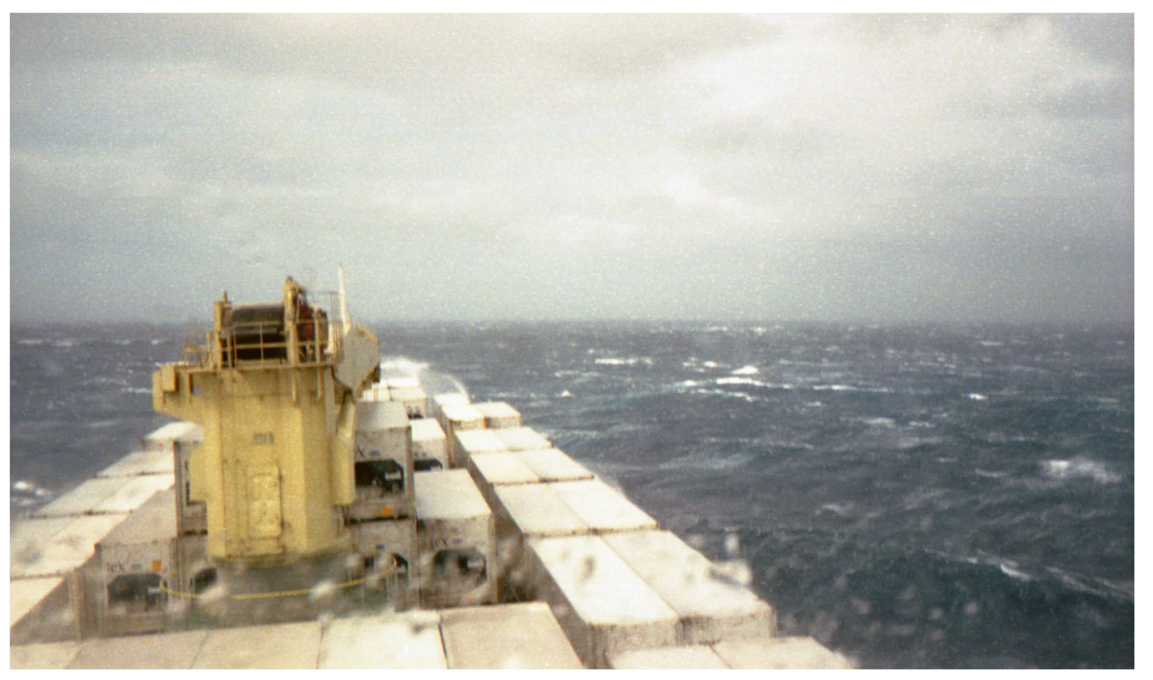

Fig. 3 Waves on Cargo. Photograph was taken by a participant of waves coming near the cargo.

(see Fig. 3), one hurricane, three longshoremen died in area ports, and one seafarer and one longshoreman were severely injured. The chief cook, the DJ, took the photo in Fig. 2 and told me the waves were coming over the top of the ship and it felt like they were going to capsize. He then filled his cheeks with air and made a fake vomiting noise, explaining that he still feels sick during rough storms. When I asked Roberto what he does after he is injured, he said, "I just help myself. Only you can help yourself here on the ship. No one can because we are all here. Others have other jobs. You can't call them right away to help you just like that, so you should stay and manage yourself. Stay strong." Nico, another OS, said he does not think about the danger because "If you die, it is your time."

Perry, an Able-Bodied Seaman whose duties include standing watch, performing general maintenance and upkeep, and other general duties, said that he would go to the doctor if he was sick "because it's my right... because it's in the MLC." Conversely, when I asked Jonah, an Oiler on the vessel, why he did not seek medical care after being injured he explained the unwritten rules and policies that guide those choices:

[Shannon]: Have you ever been injured on board or sick? [Jonah lifted up his hand to reveal a scar] What's that?

[Jonah]: It's a cut. But I can't go to the hospital, so I stitched it myself.

[Shannon]: Why didn't you go to the hospital?

[Jonah]: Hospital thinking, I not, maybe think I'm not physically fit, maybe say go home. That's why I did the stitching myself.

When I probed Jonah further, I heard for the first time-and would hear repeated in almost every subsequent interview with seafarers-that he stitched his wound instead of seeking medical care because he feared losing his work contract. He explained that if the hospital noted him "not fit to work," the company would release him.

Jonah's experience stitching his wound without anesthesia makes clear that his choice to self-medicate was not a simple one between having and not having access to care. Access, in this sense, is not the cost of medical care or the physical availability of a hospital, but about understanding systems that may penalize you for using what is, supposedly, readily available for your use. For example, a port chaplain I worked closely with explained in detail how the dangers and stress of this particular reefer vessel's route impacted both the health of seafarers and their options for seeking long-term care,

[This route] is a tight schedule... [and] the stress levels just go through the roof because they're supposed to be here every single Monday. When the Russians had [the same route], a Captain had a heart attack from the stress. I visited him in the hospital and he was trying to get them to release him to get back to the ship because the ship had to leave at such and such time. He wasn't concerned about what was going on in his heart and he was adamant, adamant, adamant that: "I have to sail with the ship." And, it was like, "Captain, calm down," and you know when you say calm down, it's like telling them that you're not going to be there [on the ship] and he just hit the ceiling. He said, "Don't tell me calm down!" That was a rough case because he saw the writing on the wall. If he didn't sail with that ship at 5 o'clock he lost his job. And he didn't sail with the ship at 5 o'clock. The Chief Officer took command of the ship, you know, it had to stay on that route, and when it came back the next week, they had a new Captain who replaced him, and he had been sent home. And now it's on his record: 'Being relieved of command.' I lost contact with him and so I have no idea if he ever got another job. I think about him a lot.

Captain Diego also told me he is reluctant to go to the hospital because he does not want the stamp of "ill fit" on his record. He said, "The company, if you are always going to the doctor...the company will fire you because you are too expensive...once you have a history of sick, twice, they will not accept you anymore." I inquired if he was saying going to seek medical care twice meant you were considered to have a bad health history by the company and he said, "Yes, twice and they won't accept you." "And that makes it harder to go seek care, then? Because you don't want to be seen as sick," I asked. "Yeah. That's right," he said. Diego explained to me that "the expenses of the company, what they spent [on your medical care]" will determine if you can get hired back after seeking medical care. He noted that seeking medical care "especially here in America" where the medical costs are higher creates even more risk to future employment.

Another common theme throughout the interviews described the stress of making sure the fruit on the reefer vessel made it to the port on time, which then ensured it made it to stores on time. In Fig. 4, Perry, an Able-Bodied seafarer, took photos of the reefer 


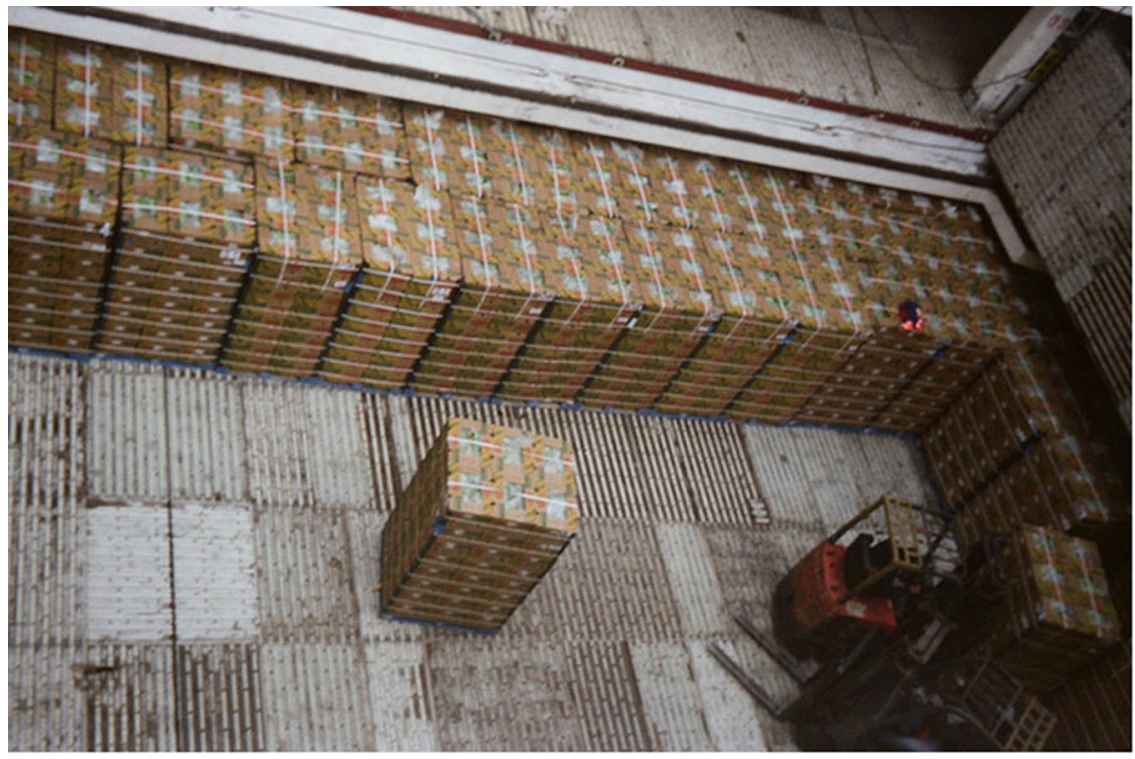

Fig. 4 Fruit in Port. Photograph was taken by a participant of fruit being loaded onto the vessel.

vessel produce being loaded onto the vessel. Seafarers discussed how if they were late, even during storms, they feared the company would hold them responsible for the delay in schedules. Pushing through storms or staying awake through shifts created an even more dangerous environment, notwithstanding the already precarious working conditions on ships, like vessel disasters, falls overboard, and illnesses with little to no medical attention (CDC, 2020). Roberto told me that "because of this kind of route we have, it's tough managing our time. We have to fix it, finish it... This [route], it's too hard for us." He explained that he has little sleep and high blood pressure due to the route. Roberto also said that their particular route was stressful and that "it's tough managing our time" because they only have a few days at sea in between ports. This was important because, as he described, being at sea provided a routine schedule. He said that when they are in port they are on-call more often and have to troubleshoot issues with the port, vessel, and various US agencies.

The route is one-week roundtrip between the Gulf of Honduras port in Guatemala and the US Gulf of Mexico port. The two ports are $\sim 1700$ miles apart and the seafarers spend between 18 and $23 \mathrm{~h}$ in each port city depending on circumstantial events, like crane operations or weather forecasts. This means seafarers are at sea about $2 \frac{1}{2}-3$ days each way. In comparison, Roberto told me the last reefer vessel he worked on had a 2-week route, giving them time to rest and maintain a semi-regular schedule. The crew arrives around midnight on Sunday night/Monday morning and leaves around midnight on Monday night/Tuesday morning. Most of the labor-intensive work happens when docked, such as loading or unloading the cargo; however, when at sea they are also responsible for ensuring the ship is maintained (see Figs. 5-7). For example, when discussing some of the photos taken by crewmembers, Roberto explained a photo-taken of him by another crewmember -that shows him repairing the cargo hold because there was so much weight that the floor collapsed (see Fig. 8).

[Shannon]: And what's the difference being at port and at sea as far as the work goes? [Roberto]: You see the pictures? That's what we do. I am lower [OS], but I have more experience... And sometimes we change the paint again. Sometimes we sweep. Fumigation. [Shannon]: In the picture, what were you repairing? [Roberto]: That's the hold, cargo hold. Repairing of the hold. Sometimes there is

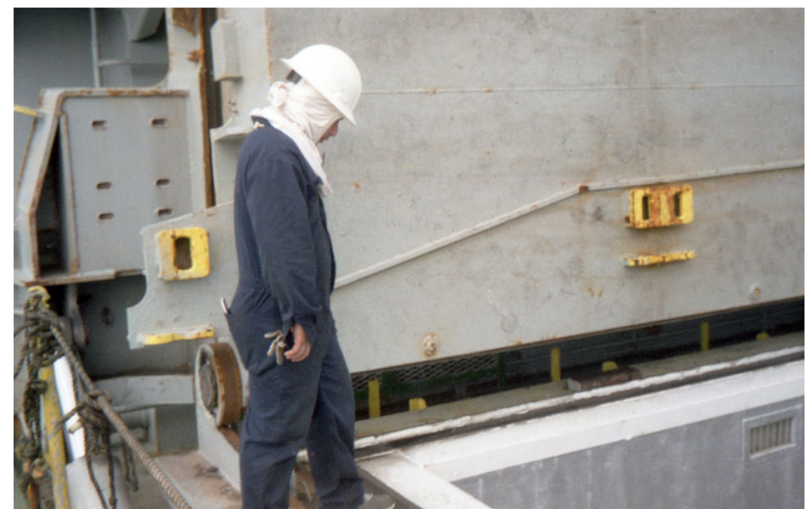

Fig. 5 Peering over the Edge. Photographs was taken by participants of seafarers working aboard the vessel while at sea.

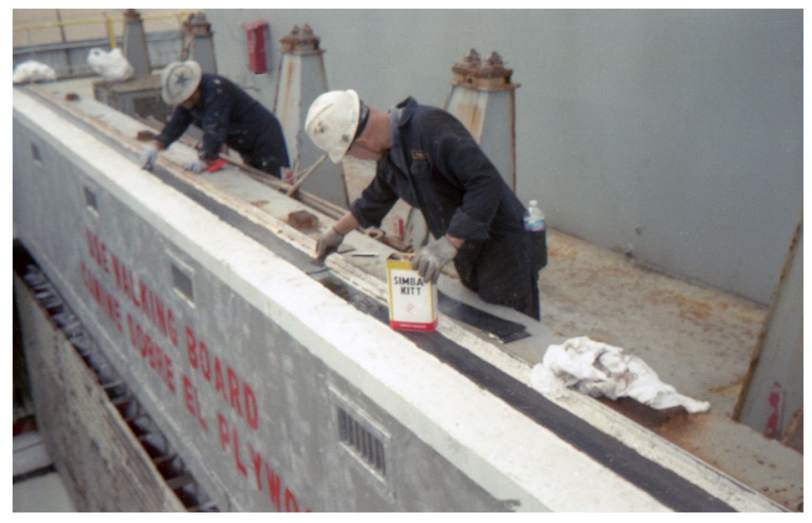

Fig. 6 Vessel Cleaning. Photographs was taken by participants of seafarers working aboard the vessel while at sea.

too much weight, the flooring collapsed, so we must repair it.

Although many aspects of seafaring are tangibly dangerous, the seafarers on this route often spoke of their lack of sleep as a major stressor. Jose, the Chief Officer on the vessel explained to me that 


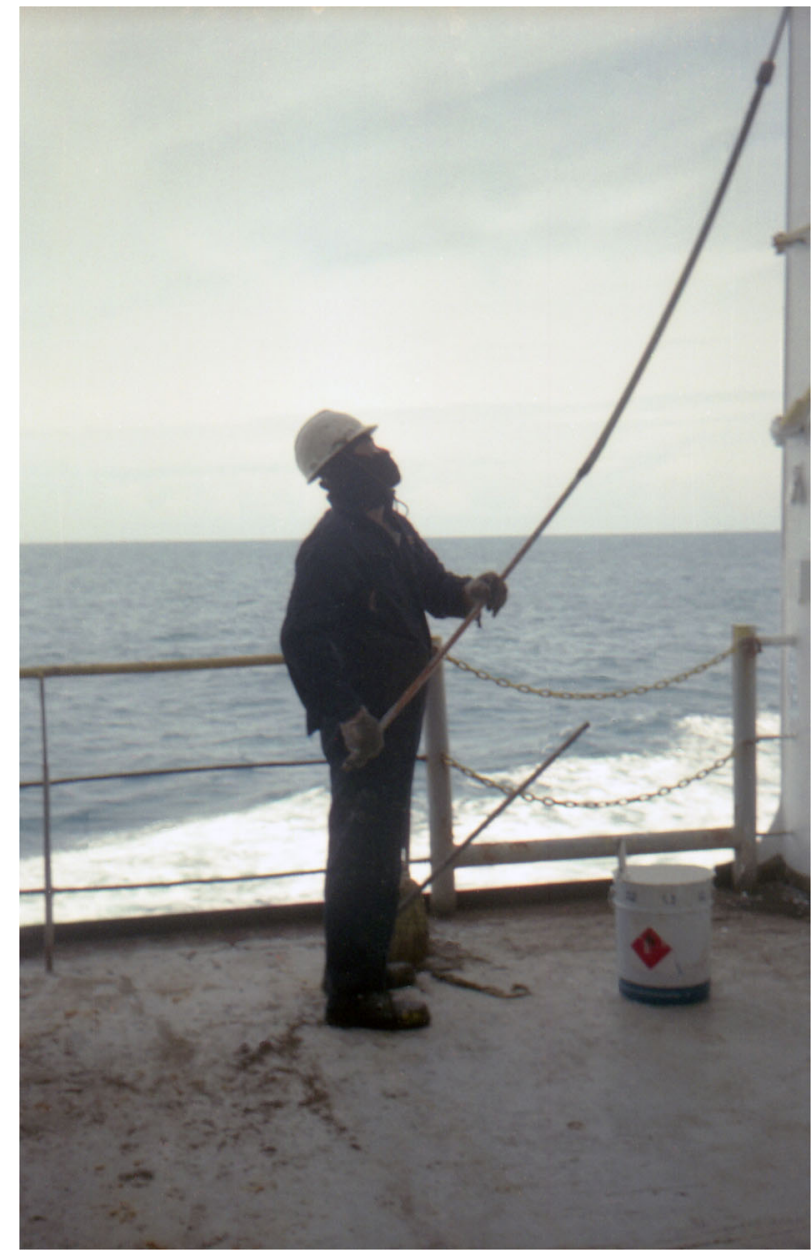

Fig. 7 Working at Sea. Photographs were taken by participants of seafarers working aboard the vessel while at sea.

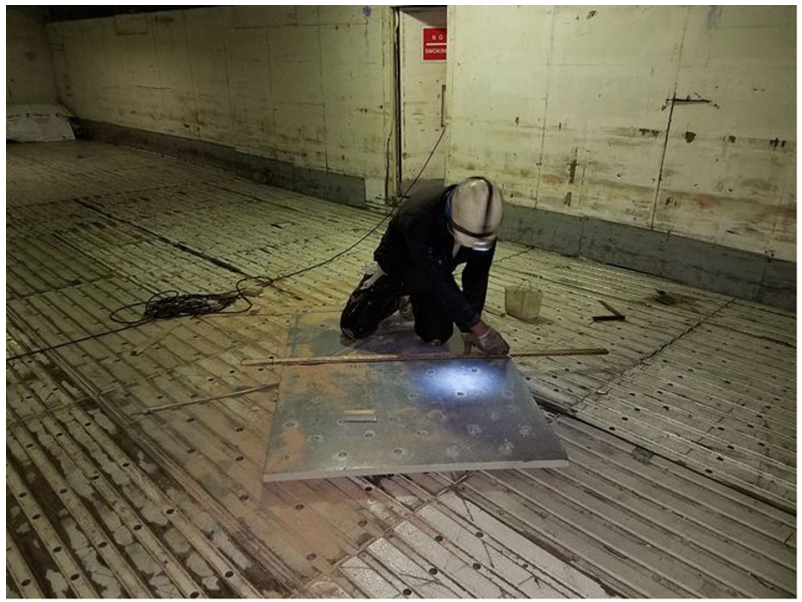

Fig. 8 Ship Repairs. A photograph was taken by a participant of a seafarer repairing the ship.

his contract includes overtime work without overtime pay: "As Chief Officer it's very stressful ... and I am awake for $24 \mathrm{~h} . .$. I don't sleep ... I am $24 \mathrm{~h}$ on call." Carlos, the Second Officer, and Medical Offer said,

Oh. It's real different than before [when I started as a seafarer in 1987]...The ships stayed longer before, you can go around and see the cities. But now, we stay only $24 \mathrm{~h}$. So, like myself and third mate we are on board working $6-6,6 \mathrm{~h}$ on, $6 \mathrm{~h}$ off. So, it's hard. If you go out, you're tired....And then this morning the Coast Guard came at 8 o'clock and they wanted to see everyone... It's okay.

Similarly, Abraham, the first Captain of the reefer vessel I met, said it is one of the most stressful routes because the company is so determined that the shipment gets to the port on time, which determines that the product gets to stores on time. I met Abraham on his last trip before Captain Deigo took command. In my field notes, I wrote that Abraham looked tired, stressed, and emotional as he told me that recent bad weather made them push through their route even harder to keep on schedule. He said none of them had slept much because they have to go so fast to make up for the weather, and the bad weather keeps them up at night. He lamented that the company gets mad when they go off schedule: "Money. Money. Money. That's all that it's about."

As demonstrated in the photos and interviews, seafaring is dangerous and stressful; despite these working conditions, seafarers found opportunities to build community. Many photos included celebrations on the ship, such as honoring crew members' children (see Fig. 9) or building community through pig roasts (see Fig. 10) and pool parties (see Fig. 11). However, these moments also highlight the difficulty of ship life and the sacrifices many of them made, such as lost time and celebrations with family or navigating workplace personalities and politics. Jay, the third officer, explained that depending on the crew, they may get along, but they may also have a "character" on board, meaning someone who is difficult to get along with or seems to create issues. He said that when he's on land, he can leave a difficult situation, but on the ship "you can go out, but it's all water."

\section{Discussion}

The seafarers I met, interviewed, and observed had experiences that mirrored many of those in the seafaring industry; mainly, the feeling that the company's lack of care was rooted in labor costs and economic liberalization (Dua, 2019). As one seafarer reported, rather bluntly, as to why companies are hiring Filipinos, "We are cheap and speak good English" (George, 2013, p. 21). As I explore below, the philosophy and ideology of neoliberalism, tied to histories of colonialism, have produced Filipinos to be poor, and then their poverty is used against them in a pervasive pursuit of profit (Harvey, 2007; Fajardo, 2011). The health inequities that follow take shape in and on their bodies, showing how social policy is embodied in higher rates of injury, illness, and death.

Current findings demonstrate how structural violence, in this case labor policies and political economic practices, discipline and exploit seafarers in particular ways, and result in practices that negatively influences the health and wellbeing of seafarers. Specifically, for Filipino migrant seafarers who work contractual jobs that pose a high risk of injury, illness, and death, structural violence is embodied through chronic pain, self-medication, and emotional anguish. Seafarers are de facto denied their de jure rights to medical care or compensation. The lived reality between de jure and de facto rights leads to a double negation because they are denied their rights (i.e., medical care), while they also deny themselves medical care as rights-bearing citizens.

The contracts Filipino migrant seafarers must sign to work overseas is an explicit example of how precarious employment is accepted by employers and employees. Precarious employment is defined as the experiences of "those associated with instability, lack of protection, insecurity across various dimensions of work, and social and economic vulnerability" (Scott-Marshall and Tompa, 2011, p. 371). The seafarer's contracts guarantee certain 


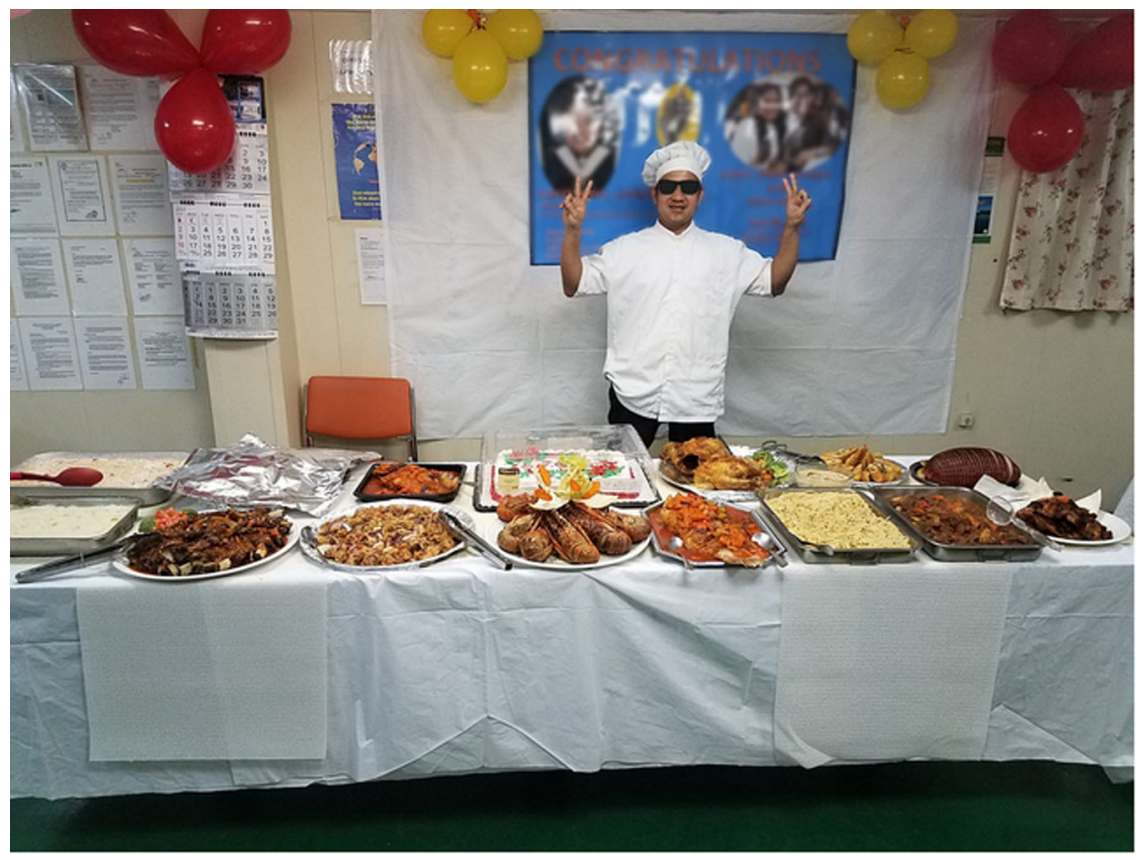

Fig. 9 Celebratory Dinner. Photograph was taken by participant of a celebration.

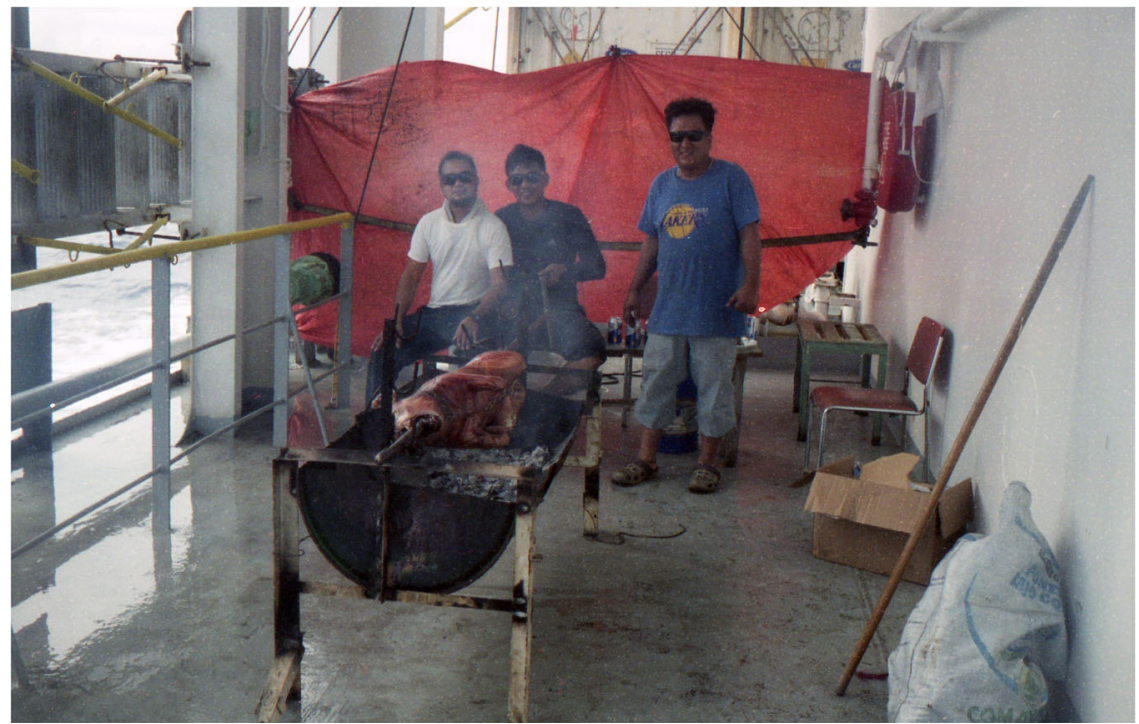

Fig. 10 Pig Roast. Photograph was taken by participant of a pig roast.

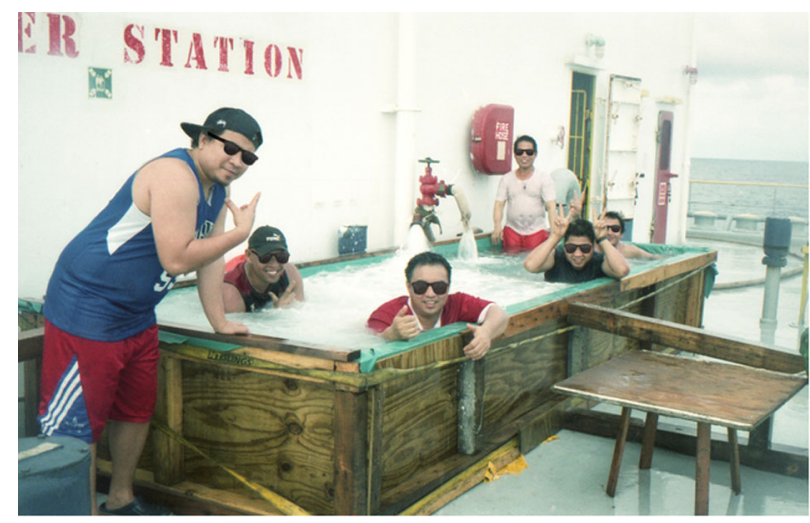

Fig. 11 Pool Party. Photograph was taken by a participant of a pool party. protections and rights, but the rights only guarantee access to health care practitioners or facilities, not continued employment if the seafarers are seen as unhealthy. In this way, companies penalize seafarers for accessing the protections guaranteed to them despite having contractual rights. The contracts for seafarers, which are typically about 9 months, must be renewed after each sea voyage. Although seafarers ideally stay with the same manning agency, the shipping contract changes frequently because seafarers are contracted to new ships, even within the same agency. The constant contract renewal adds to the precarious nature of their employment, especially if they are seen as sick or unhealthy.

Roberto, for instance, internalized his own personal responsibility for his safety ("so we must always be aware") without holding the people who produce or encourage exploitative practices accountable for policies that encourage working with little to no sleep, through injury and illness, and in dangerous storms for the profit of companies. Although he, along with other seafarers, 
did recognize and was frustrated by the quick and stressful route, Roberto frequently discussed the precarity of seafaring as his own responsibility. In the same way, the Captain who the chaplain met and who was relieved of duty embodied the structural violence that held him accountable for a heart attack that was linked to stressful company requirements.

Importantly, maritime researchers have been studying the changes in routes and the time that ships spend in ports to understand how it affects working conditions, and their frustrations are in-line with studies done among other ports (Kahveci, 1999; DeSombre, 2006). One British port study found that between 1970 and 1998, the average time a ship spent in port decreased by $16 \mathrm{~h}$ (Kahveci, 1999). Ships that left their port in $<24 \mathrm{~h}$ (like the current participants) increased from $11 \%$ in 1970 to over $70 \%$ in 1998 (Kahveci, 1999). During this period (1970-1998), ships became larger and carry even more cargo (Kahveci, 1999).

The changes to routes show how regulatory shifts in the company and government policy have a direct impact on the physical, mental, and social health of seafarers. Similarly, implicit or unwritten policies further problematize the health of seafarers. Perry, along with many human rights advocates in the maritime industry, viewed the right to seek medical care as a fundamental right for seafarers that goes back centuries. However, the right to seek healthcare is different from the lived reality of seeking healthcare, such as wage loss or losing future contracts. Seafarers' physical access to healthcare services is theoretically attainable, but the day-in and day-out real practices of seeking healthcare services is a more complicated and convoluted picture.

There is a consensus among the maritime lawyers, advocates, deckhands, and Captains I interviewed that to keep future employment opportunities available, migrant seafarers rarely seek medical care. Seafarers will self-medicate or find alternative treatments to keep their particular jobs since there is a population of other would-be migrant seafarers who can easily fill these positions. Further, to lose a seafaring contract with a company means that a Filipino migrant seafarer will need to find work in the Philippines or in lower-paying industries abroad, which means significantly less income for themselves and their families (Presser, 2017). Ideally, seafarers will seek medical treatment when needed. Realistically, they seek treatment (or are forced into treatment) only when their injury or illness is critical.

Laws and policies like maintenance and cure, the Jones Act, and the MLC can theoretically provide medical care, compensation, and other rights for those who live and work at sea, yet seafarers still do not seek medical care because of a real or perceived fear of losing future employment. Structures, like free market economies and neoliberal ideologies, shape global and public health practice. For Filipino migrant seafarers, the structural violence of deregulated, short-term contractual work is often hidden by ideologies of individual responsibility that assumes they are accountable for the effects of the system. The multiple layers of responsibility between flag states, companies, manning agencies, and ship owners further complicates their precarity because not one person, company, or government can be held fully responsible (Dua, 2019).

The logic of a profit-generating company that can treat people as commodities grows out of capitalism but is more fully realized through the growing influence and consensus of neoliberal globalization, such as industry deregulation, decreased labor power, free enterprise, and advanced notions of personal responsibility. Short-term contracts-like the 9-month contracts of migrant seafarers-most clearly illustrate the neoliberal shift of profit over people (Harvey, 2007). The individual is a factor of production, which has certain skills that are needed one day and not the next. These skills can be disregarded under short-term labor contracts, with the effect of maximizing employer benefit and employee risk. As David Harvey analyzed, "Under neo-liberalization, the figure of 'the disposable worker' emerges as prototypical upon the world stage" (2007, p. 169). The health hazards that workers experience are largely unregulated under neoliberalism, which is responsible for not only lower wages, job insecurity, and a loss of benefits, but also a loss of social protections (Harvey, 2007).

Joan Benach and her colleagues show how the global increase of flexible employment relations, higher levels of job insecurity, erosion of workers' employment and working conditions, and limited workplace rights and social protection have led to precarious employment as an emerging social determinant of health (Benach et al., 2014). For seafarers, short-term contracts, driven by neoliberalism, helped to create precarious work arrangements. The physical suffering that seafarers experience, like Jonah who sewed his wound without anesthesia, stems from structural violence. The seafarers I collaborated with worked through injuries and illness so that future employment contracts could be secured without a stamp of ill health. This is emblematic of "sickness as the embodiment of violence" (Holmes, 2013, p. 783). In this way, structural violence was embodied for Filipino migrant seafarers and rendered them more vulnerable to illness and injury. Collectively, this work with seafarers and exposes how global labor policies intimately shape individual health (Biehl and Petryna, 2013; Holmes, 2013).

\section{Conclusions}

Seafaring is not inherently unjust, even with the dangers it poses. What makes the current structure of seafaring unjust for the vast majority of Filipino migrant seafarers is that they must make the impossible choice between not seeking medical care to keep a job that pays a livable wage or seeking medical care and risking more precarious economic positions for their families. Importantly, many injustices create this situation. Historically, colonialism and postcolonialism created the possibility for Filipinos to be an ideal population for cheap migrant labor. Structurally, capitalism and neoliberal globalization made it possible to have a disposable workforce that is socially devalued. The result is physical and mental health disparities such as cardiovascular conditions, work accidents, drownings, vessel disasters, suicides, and workplace violence. Importantly, these issues are not unique to Filipino migrant seafarers, but follow global neoliberal labor movements that make migrant workers' employment more precarious through short-term contracts, thereby creating the conditions ripe for exploitation.

\section{Data availability}

The datasets used and analyzed during the current study are available from the corresponding author on reasonable request.

Received: 7 April 2021; Accepted: 21 October 2021; Published online: 12 November 2021

\section{References}

Benach J, Vives A, Amable M, Vanroelen C, Tarafa G, Muntaner C (2014) Precarious employment: understanding an emerging social determinant of health. Annu Rev Public Health 35:229-253

Biehl J, Petryna A (2013) When people come first: critical studies in global health. Princeton University Press, Princeton, NJ

Bourgois P (2007) Neoliberal lumpen abuse in the 2000s: a 25 year ethnographic retrospective on violence: https:/www.princeton.edu/ piirs/projects/ Democracy\%26Development/papers/Panel\%20I\%20\%20Bourgois.pdf

Bourgois P, Schonberg J (2009) Righteous dopefiend. University of California Press, Berkeley, CA

Catalani C, Minkler M (2010) Photovoice: a review of the literature in health and public health. Health Educ Behav 37:424-451

CDC (2020) NIOSH Program Portfolio: Center for Maritime Safety and Health Studies: Marine Transportation. https://www.cdc.gov/niosh/programs/cmshs/ marine_transportation.html 
Davies C (2009) A reflexive ethnography. Routledge, London, UK

DeSombre ER (2006) Flagging standards: globalization and environmental, safety, and labor regulations at sea. MIT Press, Cambridge, MA

Dua J (2019) The abandoned seafarer: networks of care and capture in the global shipping economy. Hist Anthropol Chur 30:497-502

Fajardo, KB (2011) Filipino Crosscurrents: Oceanographies of Seafaring, Masculinities, and Globalization. University of Minnesota Press, Minneapolis, MN

Farmer P, Sen A (2004) Pathologies of power: health, human rights, and the new war on the poor, with a new preface by the author. University of California Press, Berkeley, CA

George R (2013) Ninety percent of everything: inside shipping, the invisible industry that puts clothes on your back, gas in your car, and food on your plate. Metropolitan Books, New York

Graham CAE, Walters D (2021) Representation of seafarers' occupational safety and health: limits of the Maritime Labour Convention. Econ Labour Relat Rev 32:266-282

Harvey DA (2007) Brief history of neoliberalism. Oxford University Press, Oxford, UK

Holmes S (2013) Fresh fruit, broken bodies: migrant farmworkers in the United States. University of California Press, Berkeley, CA

International Transport Workers' Federation ITF (2006) A Seafarers' Bill of Rights. An ITF guide for seafarers to the ILO Maritime Labour Convention, 2006. The International Transport Workers' Federation, London, UK

Kahveci E (1999) Fast turnaround ships and their impact on crews. Seafarers International Research Centre

MacLachlan M, Kavanagh B, Kay A (2012) Maritime health: a review with suggestions for research. Int Marit Health 63:1-6

Maritime Labour Convention (2006) International Labour Organization. Last accessed October 2021. https://www.ilo.org/dyn/normlex/en/ $\mathrm{f} ? \mathrm{p}=$ NORMLEXPUB:91:0::NO::P91_SECTION:MLCA_AMEND_A1

Marcos F E (1982) Governing the remittance to the Philippines of foreign exchange earnings of Filipino workers abroad and for other purposes. Malacañang Records Office, Manila, Philippines

Markkula J (2021) We move the world: the mobile labor of Filipino seafarers. Mobilities 16:164-177

McDaniel VA (1990) Recognizing modern maintenance and cure as an admiralty right. Fordham Int Law J 14:669. https://ir.lawnet.fordham.edu/ilj/vol14/iss3/5

Presser L (2017) Below Deck: Filipinos make up nearly a third of all cruise ship workers. It's a good job. Until it isn't. California Sunday Mag. Last accessed October 2021. https://story.californiasunday.com/below-deck/

Rodriguez RM (2010) Migrants for export: how the Philippine State Brokers Labor to the world. University of Minnesota Press, Minneapolis, MN

Rosaldo R (1989) Culture \& truth: the remaking of social analysis. Beacon Press, Boston, MA

Scheper-Hughes N (2004) Dangerous and endangered youth: social structures and determinants of violence. Ann N Y Acad Sci 1036:13-46. https://doi.org/ 10.1196/annals. 1330.002

Scott-Marshall H, Tompa E (2011) The health consequences of precarious employment experiences. Work 38:369-382. https://doi.org/10.3233/WOR-2011-1140

Smith A (2016) Imposting justice: the prospect of mandatory arbitration for guestworkers. NYU Rev Law Soc Change 40(2):375-427

Standing G (2014) The precariat: the new dangerous class. The precariat: the new dangerous class. Bloomsbury Publishing, London, UK

Sutton-Brown CA (2014) Photovoice: a methodological guide. Photogr Cult 7:169-185

Terry WC (2009) Working on the water: on legal space and seafarer protection in the cruise industry. Econ Geogr 85:463-482
Trimble J, Fisher C, Birman D (2011) Ethical issues in research with immigrants and refugees. Handb Ethical Res with Ethnocult Popul Communities 156-177. https://doi.org/10.4135/9781412986168.n9

Wang C, Burris MA (1997) Photovoice: concept, methodology, and use for participatory needs assessment. Health Educ Behav 24:369-387. https://doi.org/ $10.1177 / 109019819702400309$

Wright T (2016) The photography handbook. Routledge, London, UK

\section{Acknowledgements}

I thank the seafarers who allowed me to interrupt the flow of their lives for interviews, observations, and photovoice, and for bestowing on me the nickname Katy Perry. I would also like to thank the following people for their thoughtful and thought-provoking comments: Rebecca Hester, Arlene Macdonald, Jerome Crowder, William Terry, Jeff $\mathrm{R}$. Temple, Ellie Cherryhomes, and Will Wright.

\section{Competing interests}

The author declares no competing interests.

\section{Ethical approval}

The study was approved by the University of Texas Medical Branch Institutional Review Board (IRB), Galveston, TX, USA.

\section{Informed consent}

All participants consented to interviews, photovoice, and observations via an Informed Consent Form.

\section{Additional information}

Correspondence and requests for materials should be addressed to Shannon GuillotWright.

Reprints and permission information is available at http://www.nature.com/reprints

Publisher's note Springer Nature remains neutral with regard to jurisdictional claims in published maps and institutional affiliations.

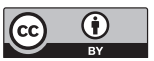

Open Access This article is licensed under a Creative Commons Attribution 4.0 International License, which permits use, sharing, adaptation, distribution and reproduction in any medium or format, as long as you give appropriate credit to the original author(s) and the source, provide a link to the Creative Commons license, and indicate if changes were made. The images or other third party material in this article are included in the article's Creative Commons license, unless indicated otherwise in a credit line to the material. If material is not included in the article's Creative Commons license and your intended use is not permitted by statutory regulation or exceeds the permitted use, you will need to obtain permission directly from the copyright holder. To view a copy of this license, visit http://creativecommons.org/ licenses/by/4.0/

(c) The Author(s) 2021 